\title{
JMI
}

\section{Idle Money pada Masjid di Kota Pontianak}

\author{
Syarifah Aulia Almuntahar,
}

Prodi Ekonomi Islam, Fakultas Ekonomi dan Bisnis, Untan, INDONESIA, Email: liamuthahar@gmail.com

\begin{abstract}
ABSTRAK
Penelitian ini bertujuan mengetahui seberapa besar uang mengendap (idle money) di masjidmasjid yang ada di Kota Pontianak. Penelitian ini dilakukan pada 30 masjid di Kota Pontianak. Penelitian ini menggunakan metode kualitatif eksploratif dan deskriptif. Hasil penelitian ini mendapati bahwa masjid-masjid di Kota Pontianak memiliki sumber dana yang beragam, dan memiliki dana mengendap cukup besar. Rata-rata Masjid di Kota Pontianak memiliki dana mengendap sebesar Rp.100.000.000. Faktor-faktor yang mempengaruhi besaran dana mengendap adalah berjaga-jaga untuk pengeluaran tak terduga, dana operasional yang besar, pola pikir takmir berpendapat bahwa dana masjid yang banyak itu baik. Penelitian ini memberikan informasi yang aktual tentang besaran dana masjid yang menganggur dan alasan pengurus melakukannya.
\end{abstract}

Kata kunci: Idle money, Masjid, Manajemen keuangan, Dana menganggur, Mengendap 


\section{PENDAHULUAN}

Masjid memiliki peran penting dalam sejarah peradaban Islam. Masjid dituntut untuk menjadi agent social change (agen perubahan sosial). Dalam menjalankan aktivitasnya, masjid memperoleh dana dari berbagai macam sumber. Sumber dana masjid secara umum berasal dari zakat, infak, sedekah, wakaf, sumbangan, bantuan, dan sebagainya (Ayub, dkk. 2007). Banyaknya sumber pendanaan masjid berkaitan erat dengan besarnya dana yang dikelola. Jumlah dana yang disumbangkan ke masjid memerlukan manajemen keuangan yang baik dan sehat.

Uang dilihat dari konsep aliran (flow concept) ibarat air jika dialirkan maka air tersebut akan bersih serta memberi manfaat. Apabila air dibiarkan menggenang dalam suatu tempat (menimbun uang) maka air tersebut akan kotor (Karim, 2007). Imam AlGhazali mengatakan bahwa menimbun uang sama halnya dengan memenjarakan uang karena uang bukanlah barang pribadi (private goods), akan tetapi public goods (milik semua orang). Karena itu, ketika uang ditarik dari sirkulasinya, maka akan memberikan manfaat sosial yang besar untuk masyarakat jika digunakan dengan tepat (Rosia, 2017).

Berikut ini adalah data tiga masjid di Kota Pontianak dengan rata-rata pendapatan, pengeluaran, idle money nya, dan lama mengendap.

Tabel 1: Data Pendapatan dan pengeluaran pada tiga masjid Kota Pontianak (pra survey)

\begin{tabular}{|c|c|c|c|}
\hline & Masjid Jami & Masjid Al Mubarak & Masjid Al Manar \\
\hline $\begin{array}{l}\text { Pendapatan } \\
\text { (per bulan) }\end{array}$ & \pm Rp.20.000.000 & \pm Rp.10.000.000 & \pm Rp.16.000.000 \\
\hline $\begin{array}{l}\text { Pengeluaran } \\
\text { (per bulan) }\end{array}$ & \pm Rp.15.300.000 & \pm Rp.4.500.000 & \pm Rp.10.000.000 \\
\hline $\begin{array}{l}\text { Idle Money } \\
\text { (tahun } \\
\text { berjalan) }\end{array}$ & \pm Rp.220.000.000 & \pm Rp.116.000.000 & \pm Rp.50.000.000 \\
\hline $\begin{array}{l}\text { Lama } \\
\text { Mengendap }\end{array}$ & \pm 2 tahun & \pm 2 tahun & \pm 1 tahun \\
\hline
\end{tabular}

Berdasarkan tabel 1, setiap bulan masjid Jami menyimpan uang \pm Rp.4.700.000, uang yang tersimpan selama satu tahun belakangan sebesar \pm Rp.220.000.0000, Selanjutnya masjid Mubarak setiap bulannya dapat menyimpan uang \pm Rp.5.500.000 uang selama dua tahun terakhir sebesar Rp.116.000.000, dan masjid Almanar menyimpan dana \pm Rp.6.000.000, per bulan sehingga disimpulkan bahwa masjid di Kota Pontianak memiliki idle money.

Ketika penyampaian jumlah saldo masjid yang dilakukan setiap khutbah Jum'at, maka banyak masjid memiliki saldo dengan nominal yang besar. Banyak orang merasa bangga dengan banyaknya saldo yang tersedia di Masjid, melihat dari semangatnya jamaah untuk berinfak dan bersedekah demi kemakmuran Masjid. Meskipun demikian kita perlu perhatikan bilamana saldo dana Masjid masih saja berjumlah besar tetapi 
jamaah di sekitar masjid kurang disatuni kesejahteraannya dari Masjid maka hal itu dinilai kurang menghadirkan fungsi masjid sesungguhnya (Kadim, dkk, 2019).

Realita masjid yang ada di Indonesia sekarang yang masih jauh dari yang diharapkan secara syariah, belum ada masjid yang benar-benar difungsikan secara ideal menurut apa yang dicontohkan pada zaman Rasulullah SAW. Secara umum, menurut Kementerian Agama RI (2010), bila dicermati perkembangannya dewasa ini masih banyak pengurus masjid yang lebih mementingkan kemegahan bangunan dari pada fungsi dan peran masjid yang sebenarnya. Inilah yang menjadi salah satu penyebab lambatnya perkembangan kesejahteraan umat Islam. Krisis peran masjid dan pengelolaan dana masjid perlu ditinjau kembali. Maka dari itu penulis akan mengangkat judul "Idle Money pada Masjid di Kota Pontianak."

Berdasarkan realita masjid yang ada di Indonesia didapat sebagian besar belum melaksanakan fungsinya secara optimal padahal memiliki pendapatan yang bisa dikatakan berlimpah. Berdasarkan wawancara pra survei kepada pengurus di tiga masjid memiliki dana mengendap yang cukup banyak. Oleh karena itu, peneliti menjadi tertarik untuk meneliti masalah yang terkait dana-dana yang ada pada Masjid di Kota Pontianak. Tujuan riset ini adalah (1) mengetahui berapa idle money di masjid (2) faktor penyebab adanya dana mengendap setiap masjid. Dengan demikian penelitian ini diharapkan mampu memberi wawasan serta mendorong pembenahan tata kelola keuangan maupun administrasi bagi masjid-masjid.

\section{LANDASAN TEORI}

Idle money adalah uang yang tidak menghasilkan pendapatan apapun seperti bunga, bagi hasil, dana tidak produktif serta kaitan dengan inflasi (Mahardiningtias,2018). Uang dalam pandangan Al Ghazali dan Ibnu Khaldun, jauh belum Adam Smith menulis buku "The World of Nations" pada tahun 1766 di Eropa, Abu Hamis Al Ghazali dalam kitabnya "Ihya Ullumuddin" telah membahas fungsi uang dalam perekonomian. Uang berfungsi sebagai media pertukaran, namun tidak dibutuhkan untuk uang itu sendiri. Maksudnya, uang diciptakan untuk memperlancar pertukaran dan menetapkan nilai yang wajar pada pertukaran.

Uang dalam ekonomi Islam bersifat flow concept bukan stock concept (Ilyas, 2016). Artinya uang harus mengalir, beredar di kalangan masyarakat dalam kehidupan ekonomi. Uang adalah public goods (milik masyarakat) dan oleh karenanya penimbunan uang (atau dibiarkan tidak produktif) berarti mengurangi jumlah uang beredar. Implikasinya, proses pertukaran dalam perekonomian terhambat. Di samping itu penumpukan uang/harta juga dapat mendorong manusia cenderung pada sifatsifat tidak baik seperti tamak, rakus, dan malas beramal (infak, sedekah, dan zakat), Islam melarang penumpukan/penimbunan harta, memonopoli kekayaan, "al khazu".

Dalam Islam tidak diperbolehkan menimbun harta, namun menganjurkan untuk menabung. Menabung dan menimbun adalah suatu yang berbeda (Ilyas, 2016). Penimbunan berarti pengumpulan uang satu dengan yang lain tanpa ada kebutuhan, dimana penimbunan akan menarik uang dari pasar. Mengumpulkan harta semacam ini termasuk katagori tindakan yang tercela. Lain halnya dengan menyimpan uang karena kebutuhan, semisal membangun rumah atau keperluan lain. Aktivitas menabung telah 
diajarkan dalam Islam dan dapat diteladani dari kisah nabi Yusuf AS yang tercantum pada QS. Yusuf ayat 47-48:

Artinya: Yusuf berkata "Supaya kamu bertanam tujuh tahun (lamanya) sebagaimana biasa; maka apa yang kamu tuai hendaklah kamu biarkan dibulirnya kecuali sedikit untuk kamu makan. Kemudian sesudah itu akan datang tujuh tahun yang amat sulit, yang menghabiskan apa yang kamu simpan untuk menghadapinya (tahun sulit), kecuali sedikit dari (bibit gandum) yang kamu simpan.

Pengeluaran konsumsi rumah tangga yaitu pengeluaran yang dilakukan oleh rumah tangga untuk membeli barang-barang dan jasa-jasa untuk kebutuhan hidup sehari-hari dalam suatu periode tertentu (Hidayat, 2010). Teori konsumsi menurut pusat pengkajian dan pengembangan ekonomi Islam (P3EUII, 2011) adalah pemenuhan kebutuhan barang dan jasa yang memberikan kebaikan dunia serta akhirat bagi konsumen itu sendiri baik manfaat intelektual, fisik, material, ataupun spiritual.

Pengelolaan keuangan publik digunakan oleh pemerintah untuk membiayai pembelanjaan. Fokus keuangan publik mempelajari pendapatan dan belanja pada alokasi sumber daya distribusi pendapatan, dan stabilitas ekonomi. Rasulullah SAW, memberikan arti penting bagi pembangunan Masjid, yang memiliki fungsi dan peranan dominan dalam kehidupan umat Islam, beberapa diantaranya adalah: (Kurniawan, 2014)

1. Sebagai tempat ibadah

2. Sebagai tempat menuntut ilmu

3. Sebagai tempat pembinaan jemaah

4. Sebagai tempat dakwah dan kebudayaan Islam

5. Sebagai pusat kaderisasi umat

6. Sebagai basis kebangkitan umat Islam

Secara singkat dapat dikatakan fungsi masjid merupakan tempat berkumpulnya orang-orang dengan segala aktivitasnya sekaligus tempat pemberdayaan umat (Sofwan, 2013).

Demi mendukung keabsahan penelitian, berikut penelitian terdahulu yang telah diambil dari beberapa jurnal Penelitian Haq dan Dewi (2013) "Praktik Manajemen Keuangan Masjid dan Potensi Dana Masjid" menunjukan bahwa masjid di Kota Bogor melakukan penganggaran secara sederhana dalam perencanaan kegiatan masjid. Masjid memiliki dana surplus yang seharunya dapat dimanfaatkan untuk kebutuhan masyarakat. Kemudian penelitian Fahmi (2017) "Manajemen Keuangan Masjid di Kota Yogyakarta" menyatakan bahwa sumber dana didominasi oleh infak Jumat sedangkan pemeliharaan fisik adalah pengeluaran terbanyak. Rata-rata saldo surplus Masjid di Yogyakarta adalah 45,8 juta dan paling banyak disimpan di Perbankan Umum non Syariah. Dapat diperkirakan surplus dana masjid di Kota Yogyakarta berkisar 22 Milyar. Selanjutnya Penelitian Adnan (2012) "The Financial Management Practies of the Mosque in the Special Region of Yogyakarta Provinces Indonesia" Menunjukan bahwa adanya estimasi dana masjid yang menganggur sekitar 300 milyar yang berasal dari 
infak/shadaqah di setiap Masjid. Penelitian selanjutnya yang diteliti oleh Isa dan Omar (2015) yang berjudul "Pengurus Kewenangan Dana Masjid satu kajian di daerah, Kubang Pasu, Kedah" menunjukan bahwa Masjid di Kubang Pasu Kedah setiap bulannya masjid dapat menyimpan dana sebesar RM. 3700 yang dapat disetarakan dengan kurang lebih Rp. 12 juta.

\section{METODELOGI PENELITIAN}

Penelitian ini merupakan jenis penelitian lapangan (field research) yaitu pengamatan langsung ke objek yang diteliti guna mendapatkan data yang relevan. Dengan menggunakan pendekatan kualitatif, dimana peneliti dapat menentukan hanya beberapa objek saja yang menjadi sampel dalam penelitian ini. Penelitian ini dilakukan pada bendahara masjid atau ketua masjid. metode pengumpulan data menggunakan kuesioner, wawancara, observasi dan dokumentasi. Penelitian berjumlah 30 sampel dengan pembagian setiap kecamatan diambil 5 sebagai perwakilan dari masjid pada kecamatan tersebut. Dalam penelitian ini variable yang digunakan adalah Usia masjid, status sosial masyarakat sekitar, kegiatan masjid, idle money pada masjid, pendapatan masjid, pengeluaran masjid, usaha masjid, dan faktor faktor yang mempengaruhi idle money

\section{HASIL DAN PEMBAHASAN}

Ada tiga aspek yang menjadi dasar dalam penelitian ini yaitu: identitas masjid, arus kas masjid dan dana yang mengendap di masjid. Ditinjau dari aspek arus kas masjid pertama, masjid memiliki sumber dana yang beragam dan bisa dikatakan berlimpah, ini dikarenakan dengan bertambah umat Islam setiap tahun dan religiusitas juga meningkat maka masyarakat mengetahui serta sadar akan adanya pendistribusian harta terlebih adanya kewajiban seorang manusia diciptakan menjadi khalifah di bumi Qs. Al-Baqarah (2):30, anjuran tolong-menolong Qs. Al-Maidah (5):2 dan harta yang tidak boleh digunakan hanya pada kalangan orang kaya Qs. Al-Hasyr (59):7.

Kedua, masjid sebagai sektor publik yang memiliki fungsi yang besar untuk masyarakat. dengan itu, masjid memiliki pengeluaran yang cukup besar untuk memenuhi kebutuhan masjid sehingga mendorong atau mempermudah ibadah. Ketiga, mengingat masjid adalah lembaga nirlaba yang dipercayakan oleh masyarakat (publik) kepada pemegang tanggung jawab dalam hal ini para pengelola masjid, maka masjid termasuk salah satu lembaga yang sangat membutuhkan laporan keuangan guna pengelolaan dana masjid dapat berjalan dengan baik.

\section{Idle Money}

Dari hasil wawancara didapati usia masjid tidak berpengaruh besar terhadap idle money karena masjid yang berumur tua tidak semuanya memiliki dana yang mengendap dan sebaliknya tidak semua masjid yang berumur muda tidak semuanya memiliki dana yang sedikit maka bisa dikatakan bahwa usia masjid tidak mempengaruhi jumlah idle money pada masjid. Begitu pula dengan status sosial masyarakat, belum tentu masyarakat sekitar masjid memiliki status sosial atas atau menengah keatas memiliki idle money yang relatif tinggi dan sebaliknya dan belum tentu masjid yang memiliki idle money yang relatif tinggi berada pada kalangan 
masyarakat menengah kebawah maka dapat dikatakan bahwa status sosial masyarakat disekitar masjid tidak mempengaruhi tingginya idle money pada masjid.

Masjid memiliki sumber pendapatan yang berasal dari berbagai instrumen, sumber pendapatan masjid terbagi menjadi dua yaitu umum dan khusus. Dimana sumber pendapatan khusus didapat dari masyarakat yang tujuannya diperuntukkan sesuatu yang ada di masjid antara lain fardu kifayah, zakat fitrah, dan sebagainya. Terkait sumber pendapatan umum didapat dari infak, sedekah, hasil sewa, keuntungan dari kerja sama, donatur, dan dari sumbangan pemerintah. Sumber pendapatan umum dapat dipergunakan untuk segala macam keperluan masjid dan jamaah masjid yang sesuai dengan anggaran dan maslahat dari pengeluaran tersebut. Seperti listrik, PDAM, kegiatan rutin, dan sebagainya.

Sumber utama pendapatan masjid di kota Pontianak berasal dari infak salat Jumat, dan kotak infak. Ini adalah salah satu cara khusus dari takmir masjid untuk mendapatkan dana lebih besar, ketika berlangsungnya khutbah salat Jumat kotak infak Jumat dijalankan maka dari itu tidak ada alasan bagi masyarakat untuk tidak berinfak.

Dari penelitian lapangan ditemukan, faktor banyak atau sedikit pendapatan masjid didorong oleh lokasi, jenis masjid dan kegiatan masjid. Masjid yang berada di pusat kota, perkantoran, di pinggir jalan raya, masjid bersejarah, masjid raya yang sering dikunjungi oleh masyarakat, relatif memiliki pendapatan yang lebih besar dibandingkan dengan masjid lainnya.

Masjid di Kota pontianak memiliki rata-rata pendapatan Rp.13.123.000 per-bulan sedangkan pengeluaran rata-rata Rp.10.489.000 per-bulan dan per-masjid. Jika pendapatan dikurangi pengeluaran rutin maka setiap masjid dapat mengendapkan dananya berkisar \pm Rp.2.634.000 per-bulan maka jika dikalikan dengan jumlah masjid di Kota Pontianak dana yang mengendap Masjid di Kota Pontianak sebesar Rp.903.8462.000 setiap bulan, akumulasi satu Rp.10.841.544.000 Ini membuktikan masjid adalah lembaga yang dipercayai oleh masyarakat Kota Pontianak untuk mendistribusikan dana bagi kepentingan umat.

Hasil wawancara yang dilakukan oleh peneliti bahwa seluruh masjid tidak ada yang mengalami defisit anggaran karena pendapatan masjid lebih besar dari pengeluaran masjid dan tidak pernah ada masalah untuk pengumpulan dana. Hal ini juga ditemukan pada studi yang dilakukan oleh Hussin, dkk di malaysia yang berjudul Economic Significance of Mosque Institution in Perak Malaysia. bahwa hampir semua masjid tidak mengalami defisit anggaran dan dapat bisa dikatakan bahwa posisi keuangan yang relatif baik untuk sebuah lembaga non-profit.

Mayoritas masjid di Kota Pontianak memiliki dana yang mengendap berkisar Rp.100.000.000 yaitu 47\% dan hanya 1 masjid yang dananya kurang dari Rp.1.000.000 jadi jika dijumlahkan masjid di Kota Pontianak memiliki dana Rp.3.498.246.000 dan jika di rata-rata maka setiap masjid memiliki dana yang mengendap Rp.116.608.866 jumlah ini jauh lebih besar dari penelitian-penelitian sebelumnya yaitu pada penelitian Adnan Rp.42.159.151 dan penelitian Fahmi bahwa rata-rata saldo mengendap masjid di Kota Yogyakarta Rp.45.866.365 dan jika dikalikan jumlah masjid di Kota Pontianak total dana mengendap Rp.39.306.036.266.666. Sebagian besar masjid memiliki peluang mengendapkan dana $\leq$ Rp.0 - Rp.10.000.000 dan jika dilihat dari seluruh masjid 
didapat mayoritas masjid memiliki peluang untuk mengendapkan dana pada rata-rata Rp.4.000.000 - Rp.6.000.000. Per-bulan masjid dapat menyisihkan Rp.2.787.766.

Tabel 2: Rata-rata Pendapatan dan Pengeluaran Masjid per bulan

\begin{tabular}{|c|c|c|c|}
\hline $\begin{array}{l}\text { Pendapatan } \\
\text { Masjid }\end{array}$ & $\begin{array}{l}\text { Pengeluaran Rutin Masjid } \\
\text { (Dalam Rupiah) }\end{array}$ & Frekuensi & Persentase \\
\hline \multirow{4}{*}{$<5.000 .000$} & $1.000 .000-5.000 .000$ & 7 & $23 \%$ \\
\hline & $5.000 .001-10.000 .000$ & - & $0 \%$ \\
\hline & $10.000 .001-15.000 .001$ & - & $0 \%$ \\
\hline & $>15.000 .000$ & - & $0 \%$ \\
\hline \multirow{4}{*}{$\begin{array}{l}5.000 .000- \\
10.000 .000\end{array}$} & $1.000 .000-5.000 .000$ & 5 & $17 \%$ \\
\hline & $5.000 .001-10.000 .000$ & 2 & $7 \%$ \\
\hline & $10.000 .001-15.000 .000$ & - & $0 \%$ \\
\hline & $>15.000 .000$ & - & $0 \%$ \\
\hline \multirow{4}{*}{$\begin{array}{l}10.000 .000 \\
15.000 .000\end{array}$} & $1.000 .000-5.000 .000$ & 3 & $10 \%$ \\
\hline & $5.000 .001-10.000 .000$ & 1 & $3 \%$ \\
\hline & $10.000 .001-15.000 .001$ & 2 & $7 \%$ \\
\hline & $>15.000 .000$ & - & $0 \%$ \\
\hline \multirow{4}{*}{$>15.000 .000$} & $1.000 .000-5.000 .000$ & - & $0 \%$ \\
\hline & $5.000 .001-10.000 .000$ & 1 & $3 \%$ \\
\hline & $10.000 .001-15.000 .001$ & 6 & $20 \%$ \\
\hline & $>15.000 .000$ & 3 & $10 \%$ \\
\hline \multicolumn{2}{|l|}{ Jumlah } & 30 & $100 \%$ \\
\hline
\end{tabular}

Sumber: Hasil Pengolahan Data Primer (Data diolah, 2020)

Dari hasil penelitian terdapat masjid yang memiliki pendapatan dan pengeluaran yang besar dikatakan bahwa pendapatan dan pengeluaran sama padahal jika dilihat dari observasi lapangan masjid sebesar itu tidak mungkin memiliki surplus dana yang kecil ataupun defisit. Tetapi masjid Ikhwanul mukminin yang berada di sungai raya dalam memiliki pendapatan dan pengeluaran rutin yang sama dikarenakan banyak uang yang diperlukan untuk operasional dan banyak kegiatan masyarakat yang mendukung kesejahteraan umat, maka dari itu adanya perbedaan antar teori pendapatan dan tabungan dimana jika pendapatan naik maka tabungan juga naik. Tidak halnya dengan masjid ikhwanul mukminin ini.

Selanjutnya, masjid yang memiliki pendapatan besar dan pengeluaran relatif kecil menyebabkan banyak dana mengendap seperti masjid Jami Sultan Syarif Abdurrahman. Hal ini dikarenakan pertambahan dana yang besar namun tidak di imbangi pengeluaran yang sesuai. semakin hari semakin bertambahnya pendapatan yang cukup besar akan tetapi pengeluaran yang hanya sebatas keperluan sehari hari.

Untuk mempertanggungjawabkan amanahnya, takmir masjid mempublikasi keuangan, ketika sebagian umat berkumpul yaitu ketika salat Jumat kesempatan ini digunakan oleh takmir masjid guna memberitahu umat mengenai dana masjid, ringkasan informasi keuangan seperti jumlah yang terkumpul dalam minggu sebelumnya, dan berapa banyak akumulasi saldo. Dana yang disimpan oleh masjid 
mayoritas disimpan di Bank Syariah sebesar 50\%. Dikarenakan sebagian besar takmir masjid berpendapat bahwa lebih baik mempercayai Bank syariah untuk menyimpan dana masjid dan hal ini mengidentifikasi bahwa takmir masjid lumayan memahami akan pentingnya perbankan syariah sedangkan 30\% dana masjid di Bank konvensional dengan tujuan mempermudah proses transaksi.

Sesuai penelitian seluruh Masjid di Kota Pontianak sudah mencatat arus kas keuangan masjid serta mempublikasikan laporan keuangan setiap pekan kepada masyarakat pada saat khutbah Jum'at 53\% dan melalui catatan di papan masjid 47\%. Maka dapat disimpulkan bahwa takmir masjid di Kota Pontianak sudah mengetahui dan melaksanakan anjuran bahwa lembaga Nirlaba seharusnya memiliki laporan keuangan dan transparansi seperti penelitian oleh Fahmi (2017) bahwa 99,4\% masjid di Kota Yogyakarta memiliki pencatatan keuangan. Kebutuhan dan keperluan masjid tercukupi dilihat dari pengeluaran rutin yang mengindikasi masjid melaksanakan kegiatan secara lancar.

\section{Faktor yang mempengaruhi Idle money di Masjid Kota Pontianak}

Banyak hal yang menyebabkan Idle money di masjid Kota Pontianak. Merencanakan pembangunan masjid, lokasi masjid, pola pikir takmir, dan berjaga-jaga. Pertama, Motif berjaga-jaga merupakan salah satu faktor yang membuat masjid memiliki dana mengendap. Takmir pun beranggapan bahwa masjid sebagai lembaga yang besar yang cukup berpengaruh untuk keberlangsungan hidup masyarakat, terutama masyarakat sekitar haruslah memiliki dana simpanan apabila terjadi sesuatu yang tidak diinginkan atau sesuatu yang mendadak bisa ditutupi dengan uang simpanan tadi. Hal inilah yang menjadi dasar mengapa takmir masjid ingin masjid menyimpan dana yang cukup besar.

Kedua, Pola Pikir Takmir, Masjid untuk menjalankan tugasnya harus memiliki pengurus yang mempertanggungjawabkan keutuhan masjid. Setiap masjid memiliki berbagai jumlah takmir, ada yang beranggapan bahwa masjid tidak memerlukan banyak takmir karena yang diurus hanyalah masjid tidak perlulah tenaga yang terlalu banyak dan memiliki skill bawaan. Ada juga yang beranggapan bahwa semakin banyaknya takmir masjid maka akan semakin baik dikarenakan takmir tidak terlalu sibuk mengurusi masjid, supaya lebih banyak beribadah. Berdasarkan teori The Low of Diminishing Return bahwa semakin bertambahnya jumlah faktor produksi tunggal tanpa disertai dengan bertambah juga faktor lain maka akan menyebabkan penurunan dalam output. Tenaga kerja yang terlalu sedikit maka akan mengganggu keberlangsungan orang terkait, karena pada hakikatnya jika takmir masjid terlalu sedikit maka orang yang menjadi pengurus lebih banyak menyibukkan dirinya untuk keperluan masjid saja. Jika terdapat banyak tenaga kerja, maka juga akan menghambat pertumbuhan masjid. Hal tersebut dikarenakan pada dasarnya, manusia jika memiliki teman untuk berbicara maka ia akan merasakan asik dan cenderung melalaikan pekerjaanya.

Masjid di Kota Pontianak mayoritas memiliki takmir masjid yang cukup banyak dan sesuai yang sudah dipaparkan oleh penulis pada hasil penelitian bahwa sebagian besar takmir masjid berumur lebih dari 55 tahun maka inilah salah satu faktor masjid mengendapkan dana untuk berjaga-jaga. Dengan banyaknya takmir masjid maka pemikiran juga akan lebih luas dan beragam. Disinilah seperti hasil wawancara yang 
telah dilakukan penulis bahwa sangat sulit menyatukan pemikiran takmir masjid dan khususnya takmir yang berumur di atas 55 tahun. Mereka cenderung tetap menjalankan sesuai pengalaman mereka dan tidak memiliki pola kepengurusan yang seharusnya dilakukan oleh pihak yang profesional atau pihak yang mengetahui tentang ekonomi Islam, terlebih dengan manajemen dana masjid. Dari sisi kepengurusan masjid, didapati bahwa masalah utamanya adalah pola pikir takmir masjid yang mempengaruhi adanya idle money, maka dengan kata lain jumlah takmir masjid tidak berpengaruh besar adanya idle money yang berpengaruh adalah usia takmir masjid dan kesepakatan takmir masjid hasil dari perbedaan pola pikir.

Lokasi masjid berdasarkan penelitian yang ditulis oleh Isa, dkk (2015) bahwa salah satu faktor yang menyebabkan banyak dana di masjid adalah lokasi masjid, masjid yang berada di sekitar tempat umum seperti taman-taman, dan berada di tengah kota, menyebabkan pendapatan relatif tinggi hal inilah yang menyebabkan dana yang ditabung setiap bulannya juga bertambah. Berdasarkan observasi dan wawancara yang dilakukan oleh peneliti bahwa masjid yang sering dikunjungi oleh kebanyakan orang, seperti masjid raya yang memiliki bentuk yang cukup menarik yang dapat mengundang orang-orang untuk berkunjung di masjid tersebut, dan masjid-masjid yang berada di tengah kota memiliki pendapatan yang relatif tinggi.

Masjid yang bersejarah memiliki pendapatan yang cukup besar dikarenakan kesadaran masyarakat sekitar dan juga minat untuk berinfak dan sedekah cukup tinggi. selain itu dengan dikenalnya masjid tersebut sebagai tempat bersejarah maka dengan jumlah pengunjung yang hadir mampu mempengaruhi pendapatan masjid. Masjid yang berada di kalangan masyarakat yang perekonomian masyarakat sekitarnya atas dan menengah ke atas, memiliki pendapatan yang relatif tinggi, dan masjid yang masyarakat sekitarnya menengah ke bawah ataupun memiliki perekonomian yang hanya dapat dikatakan cukup untuk memenuhi kebutuhan primernya saja memiliki pendapatan yang relatif rendah.

Hal ini yang menjadi dasar masjid memiliki dana yang mengendap dikarenakan pendapatan yang semakin hari semakin meningkat dengan pengeluaran yang relatif sama. Dengan begitu sebagian masjid untuk mengurangi idle money pada masjid ia memilih untuk sering membangun fisik masjid. ini selaras dengan penelitian yang dilakukan oleh Adnan (2012) bahwa dana surplus didapat dari selisih antara pendapatan masjid dan pengeluaran masjid.

Perencanaan pembangunan takmir masjid beranggapan bahwa masjid sebagai lembaga yang besar yang cukup berpengaruh untuk keberlangsungan hidup masyarakat, terutama masyarakat sekitar haruslah memiliki dana simpanan karena masjid haruslah dibangun lebih baik untuk mendukung atau menjadi sarana beribadah masyarakat yang dapat menciptakan keamanan dan ketentraman dan rasa nyaman masyarakat untuk beribadah.

Ada cita-cita besar tentang revitalisasi fungsi masjid sebagai tempat untuk melakukan dakwah dan pemberdayaan umat. Dari hasil observasi dan wawancara bahwa rata-rata pendapatan masjid di Kota Pontianak \pm Rp.13.123.000, pengeluaran rata-rata \pm Rp.10.489.000 apabila dihitung dari pendapatan dan pengeluaran rata-rata maka masjid dapat menyisihkan dana sekitar Rp.2.600.000 setiap masjid per-bulan. 
Sedangkan dana mengendap rata-rata sebesar Rp.116.608.217 setiap masjid di Kota Pontianak. Dengan berbagai macam alasan masjid mengendapkan dananya yakni: pola pikir takmir masjid, berjaga-jaga, lokasi masjid dan adanya perencanaan pembangunan dari takmir masjid. Berdasarkan teori konsumsi dan tabungan bahwa semakin banyak pendapatan maka kecondongan untuk menabung juga ikut bertambah tetapi fakta lapangan, terdapat masjid memiliki dana besar namun tidak condong untuk ditabung. Hal ini terkait takmir yang mementingkan membantu masyarakat dan memberikan suntikan dana kepada jamaah dengan kesepakatan akad Qard serta akad kerjasama, ataupun berbentuk hibah masjid kepada masyarakat.

Pada dasarnya memakmurkan masjid dan dimakmurkan oleh masjid adalah fungsi yang sebenar-benarnya masjid, namun kenyataannya dana yang diterima masjid lebih condong ditabung. Dapat disimpulkan jika melihat berbagai prilaku takmir masjid seharusnya masjid berpotensi lebih dalam penerimaan dan pengelolaan dana bagi masyarakat sekitar yang berimbas memakmurkan dan berdaya ekonomi. Apabila dilakukan akad kerjasama selain bermanfaat bagi masyarakat tentunya berimbas baik pula bagi masjid.

Paradigma tentang pengurus masjid perlu diperbarui mengingat betapa strategis masjid bila difungsikan sebagai pematik kebangkitan umat. Bukan hanya berhenti pada megahnya bangunan masjid belaka yang menjadikan ukuran keberhasilan pengurus masjid dalam mengolah dan memajukan masjidnya. Perlu ada ide-ide baru dan segar sesuai dengan kebutuhan yang diperlukan warga lingkungan masjid setempat, sehingga masjid menjadi tujuan utama masyarakat dari berbagai persoalan.

Walaupun asumsi perhitungan mengenai potensi dana mengendap masjid di atas masih sangat kasar dan membutuhkan penelitian yang lebih lanjut, gambaran ini dapat memberikan makna bahwa masjid mempunyai potensi dana yang sangat besar untuk dimanfaatkan. Jika dana ini dikelola dengan baik maka dana surplus yang menganggur ini bisa dimanfaatkan untuk berbagai macam kebutuhan terutama untuk kebutuhan masyarakat seperti pendidikan, pangan, papan, kegiatan pembangunan masjid, pembiayaan kegiatan ekonomi syariah, maupun renovasi masjid itu sendiri.

\section{KESIMPULAN}

Hasil temuan dengan tujuan mengetahui seberapa besar idle money pada masjid di Kota Pontianak dan faktor yang melatarbelakangi, didapati sebagian besar masjid memiliki pendapatan rata-rata Rp.13.123.000, dana mengendap Rp. 900.000.000 dan paling sedikit masjid dana mengendap $\leq$ Rp.1.000.000, rata-rata pengeluaran Rp.10.489.000 apabila dirata-ratakan setiap masjid memilki dana mengendap \pm Rp.2.634.000 per-bulan. Faktor yang mempengaruhi adanya dana masjid yang mengendap yaitu: pertama, masjid memiliki sumber pendapatan yang besar dan jika hanya untuk membangun fisik masjid saja maka bisa dikatakan bahwa terdapat surplus dari pendapatan tersebut, dimana ini disebabkan pola pikir takmir masjid tentang pengelolaan dana, kedua, konsep berjaga jaga setiap masjid akan adanya pembangunan masjid, biaya tak terduga dan kegiatan besar masjid, dan yang ketiga, lokasi masjid yang menjadi penyebab adanya idle money, keempat, perencanaan pembangunan, faktor terakhir ini disebabkan takmir masjid merencanakan untuk 
membangun atau memperbaiki masjid maka dari itu dananya harus ditabung. Hasil penelitian ini hendaknya memberikan pandangan serta keterbukaan untuk pengelolaan dana masjid yang semakin baik sehingga memberikan dampak besar bagi masjid itu sendiri serta kesejahteraan umat.

\section{DAFTAR PUSTAKA}

Adnan, M. A. (2014). The Financial Management Practices of the Mosques in the Special Region of Yogyakarta Province, Indonesia. Tazkia Islamic Finance and Business Review, 8(2).

Ashadul Haq, J. A., \& Dewi, M. K. (2013). Praktik Manajemen Keuangan Masjid dan Potensi Dana Masjid (Studi Kasus pada Beberapa Masjid di Kota Bogor). Accounting Departement.

Ayub, M. E., Muhsin, \& Marjoned, R. (2007). Manajemen Masjid. Jakarta: Gema Insani .

Bustami, B., \& Hakim, M. L. (2020). Strategy of Cash Waqf Development on Gerakan Wakaf Produktif at Baitulmaal Munzalan Indonesia Foundations in Digital Era. AlTahrir: Jurnal Pemikiran Islam, 20(1), 97-119.

Fahmi, R. A. (2017). Manajemen Keuangan masjid di kota Yogyakarta. Al-Tijary, 3(1), 69-86.

Hidayat, M. (2010). Pengantar Ekonomi Syariah. Jakarta: Zikrul Media Intelektual.

Ilyas , R. (2016). Konsep Uang Dalam Prespektif Islam . Jurnal Bisnis dan Manajemen Islam Vol 4 No. 1.

Kadim, A., Sunardi, N., Lesmana, R., \& Sutarman, A. (2019). Revitalisasi Fungsi Masjid Sebagai Pusat Penguatan Manajemen Peternak Sapi Rakyat melalui Lembaga Pemberdayaan Masyarakat Terpadu (LEMPERMADU) (Studi Kasus di Masjid Ainul Yaqin Kel. Jontlak, Kec. Praya, Kab. Lombok Tengah, Provinsi Nusa Tenggara Barat). Jurnal Abdi Masyarakat Humanis, 1(1).

Karim, A. A. (2007). Ekonomi Makro Islami, Cetakan ke-2.

Kurniawan, S. (2014). Masjid dalam lintasan sejarah umat islam. Jurnal Khatulistiwa, 4(2), 169-84.

Omar, H. H., Isa, M. Y., \& Yusuff, N. (2015). Pengurus Kewenangan Dana Masjid: Satu Kajian di Daerah Kubang Pasu, Kedah. Internasional Journal of Management Studies (IJMS).

Rosia, R. (2017). Peran uang dalam pasar modal perspektif Imam al-Ghazali (Doctoral dissertation, UIN Walisongo).

Rosiana, D., \& Triaryati, N. (2016). Studi Komperatif Kinerja Keuangan Pada Bank Konvensional dan Bank Syariah Indonesia . E-Jurnal Manajemen Universitas Udayana Vol. 5 No. 2, 2016.

Sofwan, R. (2013). Penguatan Manajemen Pemberdayaan Fungsi Masjid Al-Fattah di Kelurahan Krapyak Semarang. Dimas: Jurnal Pemikiran Agama untuk Pemberdayaan, 13(2), 315-334.

Zubaidi, M. N. (2011). Mendesain Masjid Masa Depan. Jakarta: PUSTAKA INSANI INDONESIA. 